\title{
Design of Wireless Network System for Digital Village Using Wireless Distribution System (Case Study: Cijambe Village)
}

\author{
Muchamad Rusdan \\ Informatics Engineering, Sekolah Tinggi Teknologi Bandung \\ Jl. Soekarno-Hatta No.378, Bandung, Jawa Barat, Indonesia \\ rusdan@sttbandung.ac.id
}

Accepted on May 14, 2019

\begin{abstract}
The purpose of this research is to create a wireless network design in Cijambe Village using WDS so that Cijambe Village can enjoy internet services through wireless networks, which can be used to find information, communication, and market products owned by village communities. A wireless network is one of the best alternatives in building a computer network that is practical and flexible and has high mobility. Most organizations use wireless networks to support existing cable networks, but in reality, the wireless network still uses Unshielded Twisted Pair (UTP) cable media as the backbone of Access Points (AP). Cijambe Village is a village located in Paseh District, Sumedang Regency. Cijambe village is divided into two hamlets, namely Cijambe Hamlet and Parugpug Hamlet. Cijambe village has an area of 357 hectares. The research method used in this study is a qualitative descriptive research method. The steps taken in this research are analysis and design. the conclusion is that wireless network design for digital villages using Wireless Distribution System (WDS) has a better degree of flexibility than the backbone that uses Unshielded Twisted Pair (UTP) cable. Radio wave signals from $19 \mathrm{AP}$ units can reach the entire area of Cijambe Village which has an area of 357 hectares and is divided into 2 hamlets namely, Hamlet Cijambe and Parugpug Hamlet. The design made has thought of a standard level of security with routers and firewalls.
\end{abstract}

Keywords: wireless distribution system, cijambe village, wireless network, access point.

\section{INTRODUCTION}

I $\mathrm{n}$ the current information age, the internet has changed many things, especially in fulfilling the need for information and its extensive network system that creates a lot of easy access to information is no longer only connected to the internet, but also has begun to change the mobility of users who want to be connected quickly and real-time [1]. To meet the nature of mobility and always be connected a wireless solution is needed. Wireless networks are one of the technologies that are now widely used in various places, including the Village. However, some villages still cannot enjoy the technology, due to the distance of the village which is far from the City Center [2].

A wireless network is one of the best alternatives in building a computer network that is practical and flexible and has high mobility [3]. Most organizations use wireless networks to support existing cable networks, but in reality, the wireless network still uses Unshielded Twisted Pair (UTP) cable media as the backbone of Access Points (AP) [4]. The problem of using UTP cable as a backbone media can be a 
significant obstacle to locations that are difficult to reach by cables as well as villages that have long distances from the City Center and quite difficult natural conditions. One alternative solution to this problem is to implement a Wireless Distribution System (WDS). WDS is a system for developing wireless networks without having to use UTP cables as the backbone of the AP, but utilizing wireless signal lines from the AP [5].

Cijambe Village is a village located in Paseh District, Sumedang Regency. Cijambe village is divided into two hamlets, namely Cijambe Hamlet and Parugpug Hamlet [6]. Cijambe village has an area of 357 hectares [6]. Most of the residents of Cijambe Village work in the agricultural sector which produces excellent products in the form of rice and tobacco with very good quality. In addition, the food processing industry sector also has superior products, namely cassava chips and mushroom crackers [6]. Cijambe village does not yet have a wireless network infrastructure and has not been reached by the fiber optic cable network infrastructure, because the terrain is quite difficult and the distance of villages far from the city center is an obstacle. Whereas the Cijambe Village Government has a great desire to be able to have a wireless network infrastructure that is connected to the internet as one of the standard facilities provided to rural communities that can be accessed through notebooks, smartphones and other mobile devices. It is expected that the existence of these facilities can help rural communities in the process of finding information, communication and marketing of superior village products [6].

In order to overcome the existing problem constraints, the wireless network that will be designed in Cijambe Village does not use UTP cables as a backbone from the AP, because the use of UTP cables as a backbone from AP is one of the obstacles, considering that Cijambe Village has an area of 357 hectares. with a backbone that uses UTP cable has limited distance, the farther the distance traveled, the more UTP cables that must be used and will greatly affect data transmission, data flow receipts, and costs. So with the existence of these problems, it is necessary to develop wireless networks without using UTP cables as the backbone of the AP, instead utilizing wireless signal lines as the backbone of the AP.

The purpose of this study is to create a wireless network design in Cijambe Village using WDS, so that Cijambe Village can enjoy internet services through wireless networks, which can be used to find information, communication, and market products owned by village communities.

\section{LITERATURE REVIEW}

\section{A. Village}

Villages are legal community units that have territorial limits that are authorized to regulate and manage government affairs, the interests of the local community based on community initiatives, origin rights, and/or traditional rights that are recognized and respected in the Unitary State of Republic of Indonesia [7].

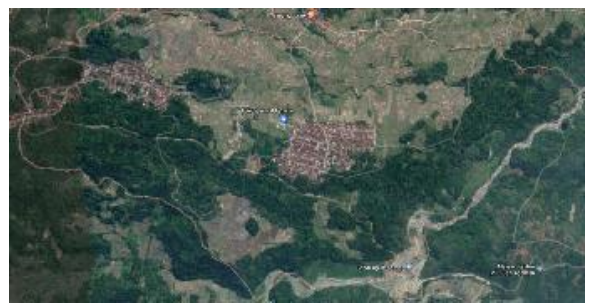

Fig. 1. Satellite Map of Cijambe Village

\section{B. Digital Village}

The Digital Village is a village area that provides a range of services to the public through computers connected to the internet, smart phones, printers, tablets, laptops and other communication infrastructure. Services that exist in digital villages including e-commerce, e-government, banking, e-learning, and communication and information services [8]. 
A Digital Village is an idea that can allow developers to reach underdeveloped areas. Physically, Digital Villages generally refer to villages connected to the Internet [9].

\section{Computer Network}

Computer network is a collection that consists of two or more computers, each of which stands alone and is connected through a media. Media that connects computers not only through copper cables, but also through fiber optics, radio waves, infrared, and satellites [10].

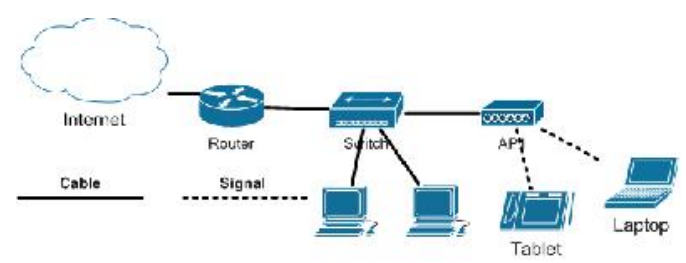

Fig. 2. Computer Network

D. Wireless Network

Wireless network is a computer network that uses radio wave frequency for communication between computer devices and access points (AP) which is the basis of two-way radio communication whose characteristics work on the $2.4 \mathrm{GHz}$ frequency $(802.11 / \mathrm{b} / \mathrm{g} / \mathrm{n} / \mathrm{ac})$ and $5 \mathrm{GHz}(802.11 \mathrm{a} / \mathrm{n} / \mathrm{ac})[11][12]$.

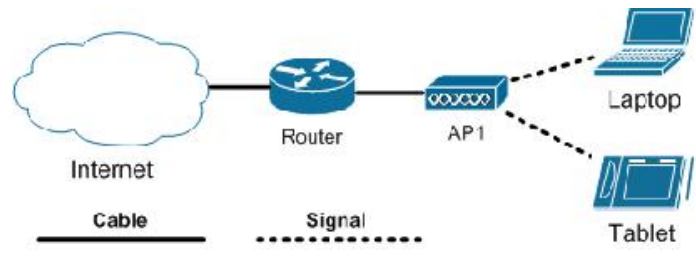

Fig. 3. Wireless Network

E. Wireless Network Topology

The wireless network has two topologies that can be used, namely:

1) Ad-Hoc

Ad-hoc or mesh topology is a very simple wireless network topology because it does not require a server to communicate with each other [13] [14].

2) Infrastructure

On wireless networks, if you want to be able to share files and printers, then the wireless network must be used in Figure 4. Infrastructure topology serves to serve the main communication on wireless networks [15]. Setting the location of an AP can expand the range of wireless networks [16].

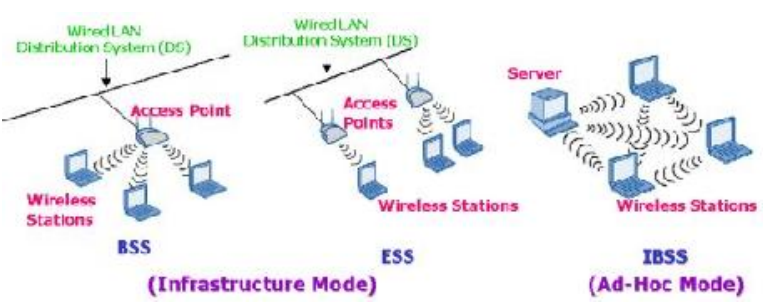

Fig. 4. Wireless Network Topology 


\section{F. Wireless Distribution System (WDS)}

WDS allows wireless networks to be developed using several APs without having to require a UTP or Fiber Optic network cable backbone to connect them [5][17]. The advantage that can be seen from WDS compared to other solutions is that with WDS, the MAC header Address of packet traffic does not change between AP links [18]. WDS has 2 topologies, namely, WDS Infrastructure and Mesh WDS, which can be seen in Figure 1 and Figure 2.

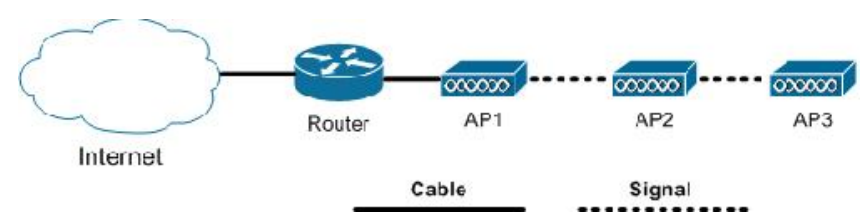

Fig. 5. WDS Infrastructure

In Figure 5 the Infrastructure WDS topology is a bit more complicated because each AP must be programmed to only receive the incoming signal from the AP upstream. Therefore, AP2 can only receive signals from AP1, and AP3 can only receive signals from AP2. This means that if AP2 is offline, AP3 will not get an Internet signal, so computers in the AP3 range do not get any internet access. What's more, the internet speed was cut in half when the signal was delivered. This means that every computer that gets Internet from AP2 gets only half the speed compared to if they get it from AP1. This also means that every computer that gets Internet from the AP3 gets 1/4 of the original speed coming out of the router. This is why the WDS infrastructure can only be arranged no more than 5 AP units. WDS infrastructure does not have redundancy in participating APs. This means that when one AP is damaged, the distribution system will be damaged. Offline APs must be replaced or repaired before all AP downlines can get a signal.

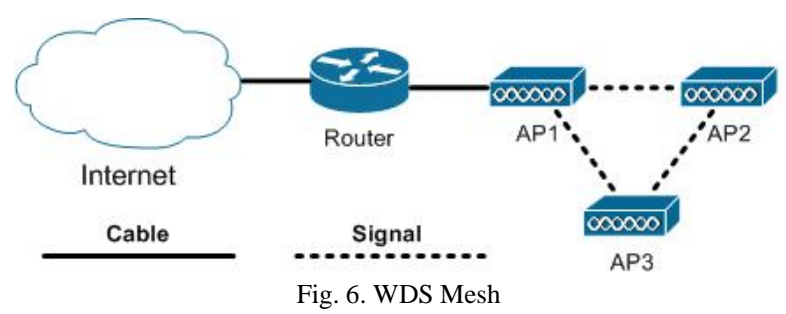

Based on Figure 6, in a mesh WDS network, all APs communicate with each other. When one AP is damaged, the other will take over its role as long as the replacement is within the source signal range. In a certain sense, the WDS mesh network can heal itself. In order for WDS mesh networks to be effective, it is necessary to add APs in strategic locations to maximize overlapping signals. This is why WDS mesh networks are stronger, but also more expensive because they need to use more APs. When the AP is offline, the internet signal flow is redirected. For example, if AP2 is offline, AP1 will communicate with AP3 via a wireless connection. While the internet connection is maintained, the computer connected to the AP3 still has two Internet speeds cut. This self-healing only works if the signal from AP1 is strong enough to reach AP3. This is why in mesh WDS networks, APs are placed at a strategic point to maximize route diversion when one or more APs are damaged.

WDS creates a wireless backbone between APs on the same wireless network. WDS devices can act as standard APs for wireless devices and bridges that connect APs together. This allows station cycle loops which means that data will not travel without limits through the network. Networks that join offer fault tolerance so that broken links will not cause network failure. Good channel distribution and several gateways can reduce network traffic load [19]. 


\section{RESEARCH METHOD}

The research method used in this study is a qualitative descriptive research method [20]. Research is carried out to determine the value of independent variables, either one or more variables without making comparisons, or connecting with other variables [21]. The steps taken in this research are analysis and design.

\section{A. Analysis}

The methods used in the analysis phase are as follows:

1) Observation

In this study, the technique of collecting data is by observing Cijambe Village, which aims to obtain a complete, clear, and definite description of the actual conditions and to get the right location points for the AP installation.

2) Interview

At this stage, interviews will be conducted with the village apparatus and the Cijambe Village community, in order to obtain a clear, complete and definite description of the existing network infrastructure, community conditions, community needs, community expectations, and supporting documentation that may be available at the Cijambe Village Office.

3) Literature Study

Literature studies are conducted by studying the literature that has to do with the object of research. In this study, supporting data were obtained from various sources such as books, magazines, journals, theses, dissertations, and websites on the internet that was in accordance with the research topic.

\section{B. Design}

At this stage, a design process will be carried out based on the results of the analysis of needs and information obtained during observation and interviews. The design that will be produced is, the design of the wireless network of Cijambe Village uses WDS in full and intact. It is expected that the design made will give a full picture of the existing needs and can be implemented in the Village of Cijambe. The application used to design wireless networks is Microsoft Visio 2016 and GNS3 Network Simulator.

\section{RESULTS AND DiSCUSSION}

From the information obtained, Cijambe Village already has a cable network infrastructure whose scope is limited only to the Village Head Office and can only be used for local or intranet connections and for internet connections still using GSM cellular modems with limited speed capacity. There is no wireless network infrastructure in Desa Cijambe at all. The reason for the absence of a wireless network infrastructure that is connected to the internet is due to hilly natural conditions, limited understanding of wireless networks, the absence of wireless network topology designs that are in accordance with the natural conditions of Cijambe Village, and fiber optic cable network infrastructure from internet service providers (ISP ) who have not reached Cijambe Village. Based on the information obtained, the authors argue that the problems faced by Cijambe Village can be solved by making a wireless network using a wireless distribution system (WDS). Before building wireless network infrastructure, it is necessary to make a complete, mature wireless network design in accordance with the natural conditions of Cijambe Village, so that the goals can be achieved and in line with expectations.

\section{A. Functional Requirements Analysis}

The functional requirements of a wireless network system that uses WDS must be as expected. The functional requirements of the system are: 
1) Wireless networks can reach all areas of Cijambe Village.

2) Wireless networks can be used by village communities to find information and communicate.

3) The wireless network is safe and user-friendly.

4) Wireless networks can be used to market superior products of rural communities.

5) Wireless networks have good signal quality.

\section{B. Non-functional Requirements Analysis}

The system designed must have capabilities that can meet system requirements. For this reason, an analysis of the needs of wireless network systems is needed to use WDS. After the analysis of system requirements is carried out, the results are obtained that the system requirements related to hardware and tools are the main needs that must be prepared. The needs of hardware and tools can be seen in table 1 .

TABLE I

NON-FUNCTIONAL REQUIREMENTS

\begin{tabular}{|c|l|c|l|}
\hline No & \multicolumn{1}{|c|}{ Name } & Qty & \multicolumn{1}{|c|}{ Description } \\
\hline \multirow{2}{*}{1} & \multirow{2}{*}{ Router Firewall } & 1 & Mikrotik RouterBoard 3011UiAS-RM \\
\cline { 3 - 4 } & & 1 & Mikrotik Router RB750 \\
\hline \multirow{2}{*}{2} & \multirow{3}{*}{ Access Point } & 2 & TP-Link CPE610 5GHz 300Mbps 23dBi Outdoor \\
\cline { 3 - 4 } & & 2 & TP-Link CPE520 5GHz 300Mbps 16dBi Outdoor \\
\cline { 3 - 4 } & & 14 & TP-Link TL-WA7210N 2.4GHz 150Mbps Outdoor \\
\hline 3 & Switch & 1 & TP-Link TL-WR840N 300Mbps Wireless Indoor \\
\hline 4 & UTP cable & 1 & TP-Link TL-SG1016D 16-Port Gigabit \\
\hline 5 & Connector & 1 & Connector RJ45 + Jacket \\
\hline \multirow{2}{*}{6} & \multirow{2}{*}{ Tower } & 1 & Tower 30 Meter \\
\hline 7 & Arrester & 5 & Tower 10 Meter \\
\hline
\end{tabular}

The reasons for choosing hardware and tools in table 1, apart from being needed to support wireless networks using WDS, are other reasons:

1) The use of a firewall router aims to enable segmentation of IP addresses, routing, and packet filtering and to make the network safe from attackers.

2) The use of TP-Link branded Access Point (AP) because it supports wireless networks with WDS and in configuration is quite user-friendly and the signal range that meets the needs.

3) The use of a 30-meter tower will be used as a place for the AP Basestation to be installed and a 10-meter tower as the place where the AP client is installed. The existence of a tower is needed because of the hilly natural conditions of Cijambe Village.

4) The use of Arrester aims to minimize device loss and damage due to lightning strikes.

\section{System Design}

After the analysis process is complete, proceed to the next stage of system design. Due to the absence of the previous network infrastructure, the design was made from the beginning, not continuing the existing one. The design is based on the results of observations to the Village of Cijambe and the Google Maps application. From the results of these activities obtained accurate information, clear images, and intact, which can facilitate and accelerate the design process carried out. Based on existing conditions and lower error rates, the wireless network topology is used, namely, a combination of Mesh WDS and WDS Infrastructure, while AP base station with station uses a Point-to-Point (P2P) connection. A clearer picture can be seen in figure 7. 


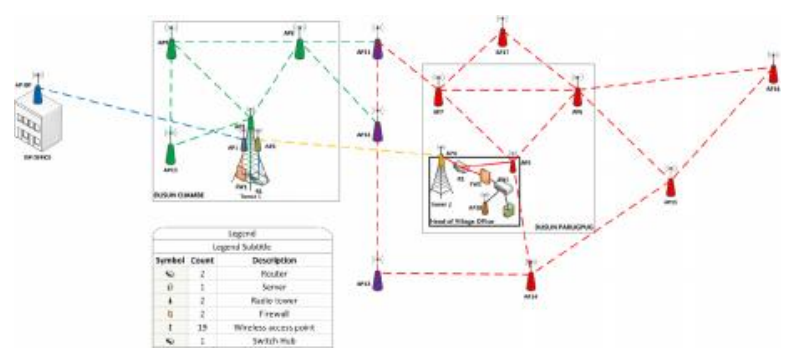

Fig. 7. Design of the Wireless Network of Cijambe Village

Based on figure 7 can be explained as follows:

1) The router device consists of R1 and R2. Router R1 functions to handle traffic and routing between ISPs with wireless networks in Desa Cijambe. Whereas router R2 to serve the data to the Office of the Village Head. The purpose of using a router is that the network can communicate despite its different network IDs, IP address segmentation, use of DHCP services, data traffic routing, and security.

2) Firewall devices used are 2 units, namely, FW1 and FW2. The function of the firewall is to control and supervise packet data flows that flow on the network, filter and control the data traffic that is permitted to access the wireless network of Cijambe Village, and authenticate access to the network.

3) Dotted lines represent radio wave signals from AP, while non-breaking lines represent network cables. So 14 AP units use radio wave signal backbone, consisting of AP1, AP4, AP6, AP7, AP8, AP9, AP10, AP11, AP12, AP13, AP14, AP15, AP16, AP17, and 5 AP units using cable backbone, consisting of from AP ISP, AP2, AP3, AP5, and AP8.

4) There are 19 units of Access Points (AP), which consist of 4 outdoor $5 \mathrm{GHz}$ AP units (AP ISP, AP 1, AP2, and AP4), 13 units of outdoor $2.4 \mathrm{GHz}$ APs (AP3, AP5, AP6, AP7, AP8, AP9, AP10, AP11, AP12, AP13, AP14, AP15, AP16, and AP17), and 1 unit of 2.4 GHz indoor AP (AP18). Naming APs from AP1 to AP18 and 1 AP ISP. The color of the AP is distinguished by its coverage area and function. Based on the color, the blue AP is the backbone AP on the Cijambe Village wireless network, which consists of the AP ISP as the base station backbone and AP1 as the backbone bridge station. The yellow AP is the AP Backbone Office of the Village Head of Cijambe, which consists of AP2 base station backbone and AP4 as backbone bridge stations. Green APs are APs that serve the Cijambe Hamlet area, which consists of AP3 as a base station while AP8, AP9, and AP10 are bridge stations that can be connected to client devices. A red AP is an AP that covers the Parugpug Hamlet, which consists of AP5 as a base station while AP6, AP7, AP14, AP15, AP16, and AP17 are bridge stations that are connected directly to the mobile client device. The purple AP is an AP that serves the border area between the Cijambe Hamlet and Parugpug Hamlets, which consists of AP11, AP12, and AP13 as bridge stations that can be directly connected to users of wireless network services. Then the brown AP with the name AP18 is an AP that specifically serves service users at the Village Head's Office.

5) Switch devices (SW1) are devices that service cable service users at the Village Head Office. The switch is connected to the wireless network Desa Cijambe through a router (R2) and a firewall (FW2) that backs it from the Access Point (AP4).

6) Installation of tower 1 and tower 2 is carried out so that the transmit power of the AP radio wave signal becomes better because the fewer obstacles the AP radio wave signal becomes more far-reaching, commonly called a line of sight (LOS). Tower 1 has a height of 30 meters and tower 2 has a height of 10 meters. The location of tower 1 in Dusun Cijambe which has a higher altitude than other areas. While the placement of tower 2 at the Village Head Office is located in Parugpug Hamlet. 


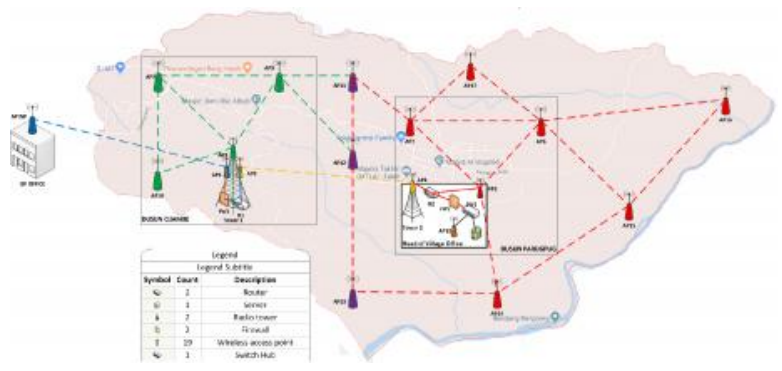

Fig. 8. Design of Wireless Network Based on Google Maps

Based on figure 8, the design of the wireless network includes all areas in Cijambe Village, which has an area of 357 hectares with 2 hamlets namely, Hamlet Cijambe and Parugpug Hamlet. Wireless network design in figure 8 can be realized if the hardware and wireless network support tools used are in accordance with the analysis of non-functional requirements that have been made or with higher specifications.

\section{Simulation of System}

In this research, a system simulation is carried out to an extent that has been made can be implemented. The process of system simulation is done using the GNS3 Network Simulator application. An overview of the simulation system can be seen in figure 9 .

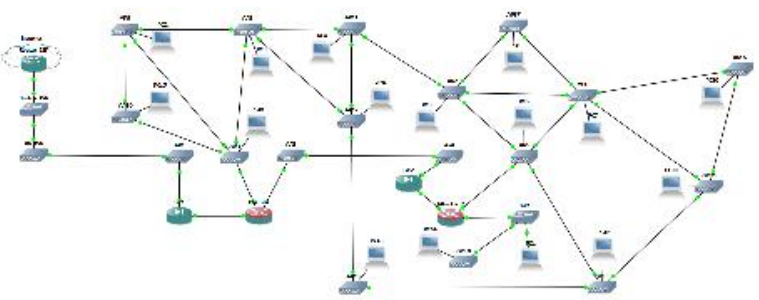

Fig. 9. Wireless Network Simulation of Cijambe Village

Based on figure 9, all APs can connect with users 'mobile devices through radio wave signals, except AP ISP, AP1, AP3, and AP4 are used as an AP backbone, which does not serve connections with users' mobile devices. From the results of simulations that have been done, the designs that have been made can be connected and communicate with data well.

\section{Conclusion}

Based on the research that has been done, the conclusion is that wireless network design for digital villages using Wireless Distribution System (WDS) has a better degree of flexibility than the backbone that uses Unshielded Twisted Pair (UTP) cable. Radio wave signals from 19 AP units can reach the entire area of Cijambe Village which has an area of 357 hectares and is divided into 2 hamlets namely, Hamlet Cijambe and Parugpug Hamlet. The design made has thought of a standard level of security with routers and firewalls. With the existence of a router eating network can be segmented by region and condition of the community, then the presence of a firewall can minimize attacks carried out by irresponsible people, who have the intention to steal data and damage the wireless network in the village of Cijambe.

\section{ACKNOWLEDGMENT}

This study was supported by the Cijambe Village Government. Thank you to the Government of Cijambe, Village Head Cijambe, Sek. Cijambe Village, BPD Chairperson, LPM Chairperson, Cijambe Hamlet Head, Parugpug Hamlet Head, and Cijambe Village Community who had assisted this research. 
Thank you to Mr. Andhika Ligar Hardhika, SE, M.Sc (Widyatama University Lecturer), Mr. Daniel TH Manurung, SE, M.SA (Widyatama University Lecturer), and Mr. Daniel Nababan, SE, M.Acc (Widyatama University Lecturer), for their cooperation and assistance in providing insight that greatly helped this research.

\section{REFERENCES}

[1] A. Tenggono, "Desain Dan Implementasi User Authentication Untuk Fasilitas Hotspot Stmik Palcomtech,” J. Teknol. dan Inform., vol. 1, no. 3, pp. 184-201, 2011

[2] H. Subiakto, "Internet Untuk Pedesaan dan Pemanfaatannya Bagi Masyarakat (The Usage of Internet for the Village and Villagers)," Masyarakat, Kebud. dan Polit., vol. 26, no. 4, pp. 243-256, 2013.

[3] A. E. Prasetyo, M. Stefanus, A. Wiem, and A. Herusutopo, "Analisis dan Optimalisasi Jaringan Nirkabel Dengan Minimalisasi Roaming Di Binus Square,” J. Comtech, vol. 5, no. 2, pp. 611-624, 2014.

[4] T. Arianto, "Implementasi Wireless Local Area Network dalam RT / RW Net," J. Teknol. Inf. Din., vol. XIV, no. 2, pp. 152$157,2009$.

[5] D. I. Haerudin, L. B. Aksara, and M. Yamin, "Implementasi Wireless Distribution System (Wds) Pada Hotspot (Studi Kasus : Smk Negeri 1 Kendari)," semanTIK, vol. 3, no. 2, pp. 105-112, 2017.

[6] A. M. Imanuddin, "Desa Cijambe," sumedangtandang.com, 2016. [Online]. Available: http://sumedangtandang.com/direktori/detail/desa-cijambe.htm. [Accessed: 21-Jan-2019].

7] P. R. Indonesia, "Undang-undang Republik Indonesia Nomor 6 Tahun 2014 Tentang Desa," 2014

[8] L. Atieno and C. A. Moturi, "Implementation of Digital Village Projects in Developing Countries - Case of Kenya," Br. J. Appl. Sci. Technol., vol. 4, no. 5, pp. 793-807, 2014.

[9] S. M. Karume, "Factors Inhibiting the Implementation of Digital Villages in Kenya," Int. J. Sci. Res., vol. 14, no. 10, pp. 2319_ 7064, 2013

[10] W. Stallings, Data and Computer Communications, 8th Editio. London: Pearson Prentice Hall, 2007.

[11] Siemens, Basic information on configuring an Industrial Wireless LAN, 5th versio. Siemens AG, 2018.

[12] M. Ji, "Designing and Planning a Campus Wireless Local Area Network," South-Eastern Finland University of Applied Sciences - Xamk, 2017.

[13] R. K. Sriramulu, "Constructing Dynamic AD-HOC Emergency Networks Using Software-Defined Wireless Mesh Networks," San Jose State University, 2018.

[14] L. Qiu, P. Bahl, A. Rao, and L. Zhou, "Troubleshooting Wireless Mesh Networks," ACM SIGCOMM Comput. Commun. Rev., vol. 36 , no. 5 , p. $17,2006$.

[15] J. Chen, S. Li, G. Chan, and J. He, "WIANI: Wireless Infrastructure and Ad-hoc Network Integration," Proc. Int. Commun. Conf., vol. 5, no. C, pp. 3623-3627, 2005.

[16] C. Parata, V. Scarpa, and G. Convertino, "Flex-WiFi: A mixed infrastructure and ad-hoc IEEE 802.11 network for data traffic in a home environment," IEEE Int. Symp. a World Wireless, Mob. Multimed. Networks, WOWMOM, 2007.

[17] D. Sudipto, "Setting Up of a Wireless Distribution System (Wds)," Jadavpur University, 2005.

[18] D. L. A. Putra and A. Subhan, "Analisa Kinerja Implementasi Wireless Distribution System Pada Perangkat Access Point 802 . 11 G," J. Ilm., pp. 1-6, 2011

[19] I. T. Haque and N. Abu-Ghazaleh, "Wireless Sodtware Defined Networking: A Survey and Taxonomy," IEEE Commun. Surv. TUTORIALS TABLE, pp. 497-516, 2016

[20] H. Mohajan, "Qualitative Research Methodology in Social Sciences and Related Subjects,” J. Econ. Dev. Environ. People, vol. 7, no. 01, pp. 23-48, 2018.

[21] C. Williams, "Research methods," J. Bus. Econ. Res., vol. 5, no. 3, pp. 65-72, 2007. 